\title{
Comparison of random amplified polymorphic DNA with restriction fragment length polymorphism as epidemiological typing methods for Mycobacterium tuberculosis
}

Department of Pathology and Microbiology,

University of Bristol, Bristol Royal

Infirmary,

Marlborough Street,

Bristol BS2 8HW, UK

C J Linton

A D Smart

H Jalal

M R Millar

Public Health

Laboratory, Bristol

Royal Infirmary

$\mathrm{J} P$ Leeming

Institute for Medical Microbiology,

University of Berne,

Friedbuehlstrasse 51, CH 3010 Berne,

Switzerland

A Telenti

T Bodmer

Correspondence to: Dr M R Millar.

Accepted for publication 24 February 1995

\begin{abstract}
Aim-To compare restriction fragment length polymorphism (RFLP) and random amplified polymorphic DNA (RAPD) methods for the epidemiological typing of Mycobacterium tuberculosis.

Methods-Thirty one M tuberculosis cultures originating from patients in the Canton of Berne in Switzerland, which had previously been typed by RFLP, were subjected to RAPD analysis. Cultures were coded so that the investigators were blind to the RFLP results until RAPD analysis was complete.

Results-The 31 cultures of $M$ tuberculosis were divided into nine groups by RFLP and eight groups by RAPD. Generally there was good correlation between the groups identified by the two techniques, with the exception of strains that had only one copy of IS6110. Both methods subdivided isolates that were placed in a single group by the other method.

Conclusions-RAPD analysis is quick, simple, and useful for the comparison of small numbers of isolates. RFLP is more reproducible and therefore better suited for the accumulation of RFLP fingerprints for long term local surveillance and large epidemiological studies.
\end{abstract}

(f Clin Pathol: Mol Pathol 1995;48:M133-M135)

Keywords: Random amplified polymorphic DNA, restriction fragment length polymorphism, $M$ tuberculosis.

Tuberculosis is still a major cause of mortality, accounting for the deaths of three million people worldwide. ${ }^{1}$ Although the prevalence of tuberculosis has declined dramatically in the last century in developed countries, there is some concern that this decline has now ceased. ${ }^{2}$ Studies investigating the spread of Mycobacterium tuberculosis have been hampered by the paucity of methods available for the discrimination of isolates. Several genetic analysis techniques have been adapted for use with $M$ tuberculosis, including restriction fragment length polymorphism (RFLP) ${ }^{34}$ and random amplified polymorphic DNA (RAPD). ${ }^{5}$

Typing by RFLP involves cutting purified genomic DNA at specific sites using a restriction enzyme. The DNA fragments generated can be compared after separation by electrophoresis. If these patterns are too complex certain bands can be selected by probing for specific DNA sequences by Southern blot hybridisation. For $M$ tuberculosis a probe specific to the small transposable element IS6110 (or 986) which is present in the majority of $M$ tuberculosis strains in between one and 20 copies has proved particularly useful. ${ }^{3467}$ Although relatively complex, requiring many steps over a number of days, this technique has gained widespread acceptance as a useful epidemiological tool, having been used successfully in investigations of the spread of tuberculosis in cities, ${ }^{8}$ hospitals, ${ }^{9}$ shelters for the homeless, ${ }^{10}$ prisons, ${ }^{11}$ and for legal purposes. ${ }^{12}$

Random amplified polymorphic DNA analysis is a less specific method of producing DNA "fingerprints". ${ }^{114}$ This technique employs the polymerase chain reaction (PCR) to amplify DNA fragments but instead of the usual pair of primers directed at a specific target a single randomly selected primer is used. This binds at multiple sites along the genome at the low annealing temperatures used; products are produced between primers binding in close proximity to opposite DNA strands. Compared with RFLP and other recently described molecular typing methods, such as mixed linker PCR, ${ }^{15}$ RAPD is more rapid and less technically demanding to perform. RAPD has been used successfully to type a variety of different bacteria $^{16-18}$ but its potential for typing $M$ tuberculosis has only recently been reported. ${ }^{5}$ The purpose of this study was to compare RFLP with RAPD for the typing of $M$ tuberculosis.

\section{Methods}

Strains of $M$ tuberculosis were isolated from 165 patients in the Canton of Berne, Switzerland, between 1991 and 1992. All isolates were characterised by RFLP analysis at University of Berne using methods described previously. ${ }^{8}$ Briefly, DNA was extracted and purified from heat inactivated cells recovered from Middlebrook medium by centrifugation. After the DNA was cut using the restriction enzyme PvuII, fragments were separated by electrophoresis in $0.7 \%$ agarose and transferred to a nylon membrane by Southern blotting. Bands containing IS6110 were located by hybridisation to a digoxigenin labelled probe complementary to a 156 nucleotide section of IS6110 and visualised using a chemiluminescence kit (Boehringer Mannheim, Switzerland). The RFLP patterns were analysed and compared with epidemiological findings. ${ }^{8}$ 
Comparison of Mycobacterium tuberculosis subgroups defined by restriction fragment length polymorphism and random amplified polymorphic DNA

\begin{tabular}{|c|c|c|c|c|}
\hline Bern ID & Patient ID & $I S 6110 \mathrm{No}^{\mathrm{a}}$ & RFLP group & $R A P D$ group \\
\hline $\begin{array}{l}\text { MTB-10 } \\
\text { MTB-13 } \\
\text { MTB-28 } \\
\text { MTB-21 } \\
\text { MTB-4 } \\
\text { MTB-17 }\end{array}$ & $\begin{array}{l}\text { MC } \\
M C \\
\text { MC } \\
\text { NL } \\
\text { MM } \\
\text { NM }\end{array}$ & $\begin{array}{l}10 \\
10 \\
10 \\
10 \\
10 \\
10\end{array}$ & $\begin{array}{l}1 \\
1 \\
1 \\
1 \\
1 \\
1\end{array}$ & $\begin{array}{l}3 \\
3 \\
\mathrm{NT}^{\mathrm{b}} \\
3 \\
3 \\
3\end{array}$ \\
\hline $\begin{array}{l}\text { MTB-30 } \\
\text { MTB-24 } \\
\text { MTB-9 } \\
\text { MTB-2 }\end{array}$ & $\begin{array}{l}\text { AfA } \\
\text { HA } \\
\text { AvA } \\
\text { NA }\end{array}$ & $\begin{array}{l}11 \\
11 \\
11 \\
11\end{array}$ & $\begin{array}{l}2 \\
2 \\
2 \\
2\end{array}$ & $\begin{array}{l}4 \\
4 \\
5 \\
5\end{array}$ \\
\hline $\begin{array}{l}\text { MTB-15 } \\
\text { MTB-12 } \\
\text { MTB-7 } \\
\text { MTB-20 } \\
\text { MTB-27 }\end{array}$ & $\begin{array}{l}\text { TK } \\
\text { ST } \\
\text { VT } \\
\text { VT } \\
\text { VT }\end{array}$ & $\begin{array}{l}6 \\
6 \\
6 \\
6 \\
6\end{array}$ & $\begin{array}{l}3 \\
3 \\
3 \\
3 \\
3\end{array}$ & $\begin{array}{l}2 \\
2 \\
\mathrm{NT}^{\mathrm{b}} \\
2 \\
2\end{array}$ \\
\hline $\begin{array}{l}\text { MTB-19 } \\
\text { MTB-29 }\end{array}$ & $\begin{array}{l}\text { FF } \\
\text { AH }\end{array}$ & $\begin{array}{l}13 \\
13\end{array}$ & $\begin{array}{l}4 \\
4\end{array}$ & $\begin{array}{l}6 \\
6\end{array}$ \\
\hline $\begin{array}{l}\text { MTB-1 } \\
\text { MTB-31 }\end{array}$ & $\begin{array}{l}\text { FA } \\
\text { ML }\end{array}$ & $\begin{array}{l}1 \\
1\end{array}$ & $\begin{array}{l}5 \\
5\end{array}$ & $\begin{array}{l}2 \\
1\end{array}$ \\
\hline $\begin{array}{l}\text { MTB-22 } \\
\text { MTB-16 } \\
\text { MTB-3 } \\
\text { MTB-18 }\end{array}$ & $\begin{array}{l}\text { BA } \\
\text { PN } \\
\text { PN } \\
\text { PN }\end{array}$ & $\begin{array}{l}1 \\
1 \\
1 \\
1\end{array}$ & $\begin{array}{l}6 \\
6 \\
6 \\
6\end{array}$ & $\begin{array}{l}8 \\
1 \\
2 \\
1\end{array}$ \\
\hline $\begin{array}{l}\text { MTB-25 } \\
\text { MTB-6 } \\
\text { MTB-26 }\end{array}$ & $\begin{array}{l}\text { NS } \\
\text { FS } \\
\text { JT }\end{array}$ & $\begin{array}{l}4 \\
4 \\
4\end{array}$ & $\begin{array}{l}7 \\
7 \\
7\end{array}$ & $\begin{array}{l}1 \\
1 \\
1\end{array}$ \\
\hline $\begin{array}{l}\text { MTB-11 } \\
\text { MTB-5 }\end{array}$ & $\begin{array}{l}\text { WM } \\
\text { RS }\end{array}$ & $\begin{array}{l}7 \\
7\end{array}$ & $\begin{array}{l}8 \\
8\end{array}$ & $\begin{array}{l}7 \\
7\end{array}$ \\
\hline $\begin{array}{l}\text { MTB-14 } \\
\text { MTB-8 } \\
\text { MTB-23 }\end{array}$ & $\begin{array}{l}\text { WR } \\
\text { AS } \\
\text { AS }\end{array}$ & $\begin{array}{l}8 \\
8 \\
8\end{array}$ & $\begin{array}{l}9 \\
9 \\
9\end{array}$ & $\begin{array}{l}\mathrm{NT}^{\mathrm{b}} \\
\mathrm{NT}^{\mathrm{b}} \\
8\end{array}$ \\
\hline
\end{tabular}

${ }^{a}$ IS $6110 \mathrm{No}=$ number of insertion elements determined by Southern blotting.

${ }^{\mathrm{b}} \mathrm{NT}=$ non-typable by RAPD. merase (HT Biotechnology), buffer (10 $\mathrm{mM}$ Tris- $\mathrm{HCl}\left(\mathrm{pH} \mathrm{9.0),} 1.5 \mathrm{mM} \mathrm{MgCl}_{2}, 50 \mathrm{mM}\right.$ $\mathrm{KCl}, 0 \cdot 1 \%$ (vol/vol) Triton X-100, 0.01\% (wt/ vol) gelatin), $20 \mu \mathrm{M}$ (each) deoxynucleoside triphosphate (Pharmacia), and $0.4 \mu \mathrm{M}$ primer. The entire $12 \mu$ l of the GeneReleaser product was used for PCR. The reaction mixtures were overlaid with two drops of paraffin oil and then incubated for three minutes at $94^{\circ} \mathrm{C}$. Forty five cycles of PCR were performed using a thermal cycler (Omnigene; Hybaid) consisting of a denaturing step for 20 seconds at $94^{\circ} \mathrm{C}$, an annealing step for one minute at $36^{\circ} \mathrm{C}$, and an extension step for one minute at $72^{\circ} \mathrm{C}$. After the final cycle there was a step of seven minutes at $72^{\circ} \mathrm{C}$. RAPD analysis was performed for each isolate using three different primers: IS986-FP (ACGCTCAACGCCAGAGACCA), IS986RP (GATGAACCACCTGACATGAC) and INS-2 (GCGTAGGCGTCGGTGACAAA). Each analysis was run in triplicate to aid interpretation of the resulting RAPD patterns. After electrophoresis in a $2 \%$ agarose gel the PCR products were visualised by ethidium bromide staining. Gels were photographed and band patterns compared visually. ${ }^{5}$

On completion of RAPD typing, codes were broken and the results were compared with those obtained by RFLP analysis.

Thirty one cultures, including representatives from each RFLP group and some triplicates, were provided for RAPD analysis at the Bristol Royal Infirmary, England. Cultures were coded so that RAPD analysis could be performed without prior knowledge of the RFLP groups. Each strain was inoculated on to Lowenstein-Jensen slopes and incubated at $37^{\circ} \mathrm{C}$ for two weeks; the resulting growth was tested for contamination by subculture on to blood agar plates incubated at $37^{\circ} \mathrm{C}$ for four days. DNA was extracted from a heat killed suspension of $M$ tuberculosis using GeneReleaser (Cambio) according to the manufacturer's instructions (microwave method). The PCRs were performed in a total volume of $50 \mu$ containing $0 \cdot 25 \mathrm{U}$ of Super TAQ poly-

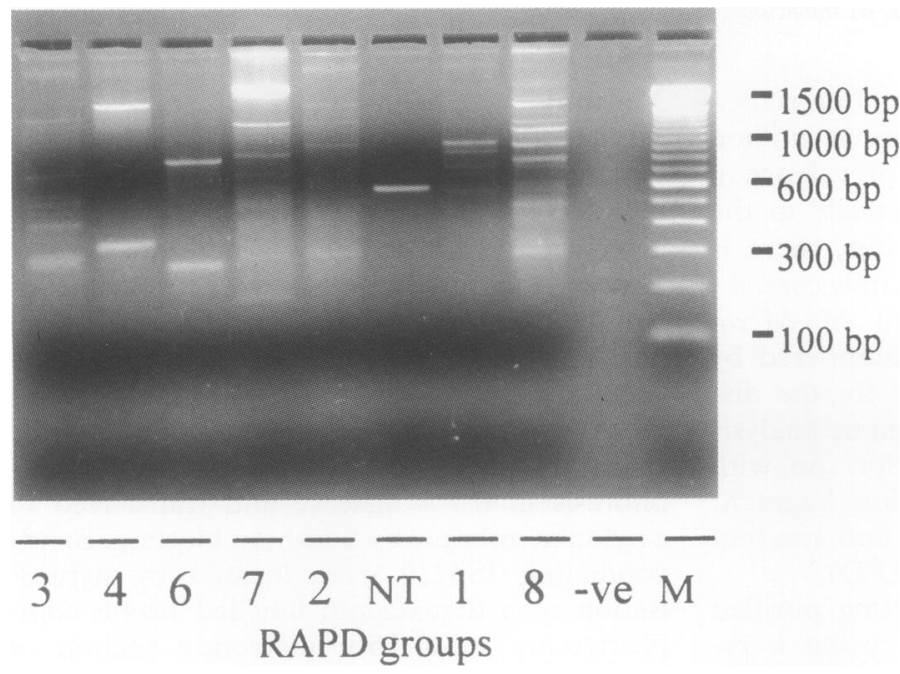

Random amplified polymorphic DNA patterns generated using the IS-FP primer for strains of Mycobacterium tuberculosis isolated from patients in the Canton of Berne. - ve = negative control; $N T=$ non-typable; $M=$ marker (100 bp DNA ladder; Gibco BRL).

\section{Results}

The $31 M$ tuberculosis cultures were separated into nine groups by RFLP; the correspondence between these groups and epidemiological data has been discussed previously. ${ }^{8}$ Twenty seven of 31 cultures were separated into eight RAPD groups as listed in the table; examples of RAPD patterns are shown in the figure. Four isolates (13\%) were recorded as non-typable because the RAPD profile consisted of a single very bright band on the gel. In our experience single amplification products are not reliably differential; this was confirmed by the observation that three of the four cultures non-typable by RAPD were in different RFLP groups.

Generally there was good correlation of the groups identified by RFLP and RAPD, with the exception of one of the three sets of triplicate subcultures provided as controls (MTB 3, 16, 18) which was incorrectly divided into two groups by RAPD analysis. RFLP groups 1, 3, 4,7 , and 8 corresponded with the RAPD groups 3, 2, 6, 1, and 7 respectively. Both methods subdivided isolates that were placed in a single group by the other method. For example isolates in RAPD groups 1 and 2 were divided into four RFLP groups (3, 5, 6, and 7) and isolates in RFLP group 2 were subdivided into two RAPD groups (4 and 5) using the primer IS-FP.

\section{Discussion}

It is notable that most of the discrepancies between the two methods occurred with isolates which had only one copy of IS6110 (RFLP groups 5 and 6); with these exceptions the two methods correlated well. The limitation of RFLP in typing strains harbouring low copy 
numbers of IS6110, particularly single copy strains, has been well documented. ${ }^{819}$ Analyses using the RAPD protocol outlined were also less reliable for strains containing few copies of IS6110; strains with single copies did not form distinct RAPD groups but clustered with strains containing multiple copies. Furthermore the set of triplicate subcultures which was divided into two groups by RAPD analysis was from a strain with a single copy of IS6110. This may in part be explained by use of primers which are all complementary to regions of this insertion sequence. ${ }^{5}$ These primers were the most discriminatory of 40 tested, perhaps because, due to specific binding of these primers, they tend to amplify selectively regions around IS6110 elements, the location of which varies in an otherwise conserved genome. ${ }^{20}$ Further investigation of RAPD using primers unrelated to IS6110 may produce more reliable results for single copy strains.

RAPD can be performed rapidly on primary isolates of $M$ tuberculosis and is a technique well suited for preliminary epidemiological studies on a small number of strains. It is, however, less reproducible than RFLP and triplicate RAPD analyses are vital in the interpretation of the banding patterns. Small numbers of isolates could be compared more easily by analysis in a single batch, with all the RAPD profiles run on the same gel, but difficulties were experienced when comparing RAPD profiles on different gels. These problems would make it difficult to establish a "library" of banding patterns for strains endemic to a particular community. The RFLP profiles are sufficiently stable for this to be possible: the IS6110 has been shown to remain stably inserted in the genome of $M$ tuberculosis for up to eight years, ${ }^{321}$ and we have documented a stable RFLP pattern for a period of six years ( $T$ Bodmer, unpublished data). It is probable that RFLP will remain the gold standard in laboratories with sufficient personnel and equipment resources.

This work was supported in part by a grant from the British Society for the Study of Infection.

1 Kochi A. The global tuberculosis situation and the new control strategy of the World Health Organisation. Tubercle 1991;72:1-6.
2 The global challenge of tuberculosis [leading article]. Lancet 1994;344:277-9.

3 van Embden JDA, Cave MD, Crawford JT, Dale JW, Eisenach KD, Gicquel B, et al. Strain identification of Mycobacterium tuberculosis by DNA fingerprinting: reMycobacterium tuberculosis by DNA fingerprinting: re-
commendations for the standardized methodology. $f$ Clin Microbiol 1993;31:406-9.

4 Hermans PWM, van Soolingen D, Dale JW, Schuitema ARJ, McAdam RA, Catty D, et al. Insertion element IS 986 from Mycobacterium tuberculosis: a useful tool for diagnosis and epidemiology of tuberculosis. F Clin Microbiol 1990; 28:2051-8.

5 Linton CJ, Jalal H, Leeming JP, Millar MR. Rapid discrimination of Mycobacterium tuberculosis strains by random amplified polymorphic DNA analysis. 7 Clin Microbiol 1994;32:2169-74.

6 McAdam RA, Hermans PWM, van Soolingen D, Zainuddin ZF, Catty D, van Embden JDA, et al. Characterization of a Mycobacterium tuberculosis insertion sequence belonging to the IS3 family. Mol Microbiol 1990;4:1607-13.

7 Thierry D, Cave MD, Eisenach KD, Crawford JT, Bates $\mathrm{JH}$, Gicquel B, et al. IS6110, an IS-like element of Mycobacterium tuberculosis complex. Nucleic Acids Res 1990;18: 188.

8 Genewein A, Telenti A, Bernasconi C, Mordasini C, Weiss $\mathrm{S}$, Maurer AM, et al. Molecular approach to identifying route of transmission of tuberculosis in the community. route of transmission of
Lancet $1993 ; 342: 841-4$

9 Nosocomial transmission of multidrug resistant tuberculosis among HIV-infected persons-Florida and New York, among HIV-infected persons-Florida
1988-1991. MMWR 1991;40:585-91.

10 Dwyer B, Jackson K, Raios K, Sievers A, Wilshire E, Ross B. DNA restriction fragment analysis to define an extended cluster of tuberculosis in homeless men and their associates. F Infect Dis 1993;167:490-4

11 Transmission of multidrug-resistant tuberculosis among immunocompromised persons in a correctional systemNew York, 1991. MMWR 1992;41:507-9.

12 Godfrey-Faussett P, Mortimer PR, Jenkins PA, Stoker NG Evidence of transmission of tuberculosis by DNA finEvidence of transmission of tubercu
gerprinting. $B M \mathcal{F} 1992 ; 305: 221-3$.

13 Welsh J, McClelland M. Fingerprinting genomes using PCR with arbitrary primers. Nucleic Acids Res 1990;18:7213-8.

14 Williams JGK, Kubelik AR, Livak KJ, Rafalski JA, Tingey SV. DNA polymorphisms amplified by arbitrary primers are useful as genetic markers. Nucleic Acids Res 1990;18: $6531-5$.

15 Haas WH, Butler WR, Woodley CL, Crawford JT. Mixedlinker polymerase chain reaction: a new method for rapid fingerprinting of isolates of the Mycobacterium tuberculosis complex. 7 Clin Microbiol 1993;31:1293-8.

16 Cancilla MR, Powell IB, Hillier AJ, Davidson BE. Rapid genomic fingerprinting of Lactococcus lactis strains by argenomic fingerprinting of Lactococcus lactis strains by ar-
bitrarily primed polymerase chain reaction with $\mathrm{P}^{32}$ and bitrarily primed polymerase chain reaction with $\mathrm{P}^{32}$ and

17 Mazurier SI, Wernars K. Typing of Listeria strains by random amplification of polymorphic DNA. Res Microbiol 1992;143:499-505.

18 Myers LE, Silva SV, Procunier JD, Little PB. Genomic fingerprinting of Haemophilus somnus isolates by using a random-amplified polymorphic DNA assay. $\mathcal{f}^{\mathrm{Clin}} \mathrm{Mi}$ crobiol 1993;31:512-7.

19 Yuen LKW, Ross BC, Jackson KM, Dwyer B. Characterisation of Mycobacterium tuberculosis strains from Vietnamese patients by Southern blot hybridisation. $7 \mathrm{Clin}$ Microbiol 1993;31:1615-8.

20 Kapur V, Whittam TS, Musser JM. Is Mycobacterium tuberculosis 15,000 Years Old? F Infect Dis 1994;170:1348-9.

21 van Soolingen D, Hermans PWM, de Haas PEW, Soll DR, van Embden JDA. Occurrence and stability of insertion sequences in Mycobacterium tuberculosis complex strains evaluation of an insertion sequence-dependent DNA polymorphism as a tool in the epidemiology of tuberculosis. f Clin Microbiol 1991;29:2578-86. 